Board of Governors of the Federal Reserve System

\author{
International Finance Discussion Papers
}

Number 553

June 1996

\title{
MACROECONOMIC STATE VARIABLES AS DETERMINANTS OF ASSET PRICE COVARIANCES
}

\author{
John Ammer
}

NOTE: International Finance Discussion Papers are preliminary materials circulated to stimulate discussion and critical comment. References in publications to International Finance Discussion Papers (other than an acknowledgment that the writer has had access to unpublished material) should be cleared with the author or authors. 


\begin{abstract}
This paper explores the possible advantages of introducing observable state variables into risk management models as a strategy for modeling the evolution of second moments. A simulation exercise demonstrates that if asset returns depend upon a set of underlying state variables that are autoregressively conditionally heteroskedastic $(\mathrm{ARCH})$, then a risk management model that fails to take account of this dependence can badly mismeasure a portfolio's "Value-at-Risk" (VaR), even if the model allows for conditional heteroskedasticity in asset returns. Variables measuring macroeconomic news are constructed as the orthogonalized residuals from a vector autoregression (VAR). These news variables are found to have some explanatory power for asset returns. We also estimate a model of asset returns in which time variation in variances and covariances derives only from conditional heteroskedasticity in the underlying macroeconomic shocks. Although the data give some support for several of the specifications that we tried, neither these models nor GARCH models that used only asset returns appear to have much ability to forecast the second moments of returns. Finally, we allow asset return variances and covariances to depend directly on unemployment rates -- proxying for the general state of the economy -- and find fairly strong evidence for this sort of specification relative to a null hypothesis of homoskedasticity.
\end{abstract}




\title{
Macroeconomic State Variables as Determinants of Asset Price Covariances
}

\author{
John Ammer ${ }^{1}$
}

\section{Introduction}

In recent years, the trading activities of major financial institutions (herein referred to collectively as "banks") have grown rapidly, and they have become increasingly concerned with managing the risk associated with exposure to unanticipated changes in the market prices of traded assets. Senior bank managers generally prefer to have this risk quantified as the sum of money that could conceivably be lost over some interval of time, given the portfolio currently held. To address this goal, banks have developed so-called "risk management models". Because the volatility of an asset price often dominates its drift over a relatively short period of time, risk management models are typically principally focused on forecasting second (and possibly higher) moments of asset returns, rather than forecasting relative mean returns. ${ }^{2}$ A risk management model has two essential components: a pricing function and a state variable probability distribution. The pricing function is a mapping from the prices or returns of traded assets to a chosen set of underlying state variables. (In

The author is an Economist in the Division of International Finance, Board of Governors of the Federal Reserve System. This paper was prepared for the joint central bank conference "Risk Measurement and Systemic Risk" (Washington, DC, November 16-17, 1995). I thank Amnon Levy for able research assistance and Mico Loretan for helpful comments. This paper represents the views of the author and should not be interpreted as reflecting those of the Board of Governors of the Federal Reserve System or other members of its staff. I am responsible for any errors.

${ }^{2}$ The focus on second moments makes risk management models useful for measuring, and perhaps designing a strategy to reduce (i.e., hedge) risk. Asset allocation models, which are used to devise trading strategies that maximize (possibly risk-adjusted) returns, have a relatively greater focus on forecasting mean returns. 
the simplest case, the set of relevant asset returns and the set of state variables are identical, but it may be advantageous to choose a smaller set of state variables.) Given the pricing function and the joint probability distribution of the underlying state variables over the relevant interval of time, it is possible to compute the distribution of possible outcomes for any portfolio.

Risk management models typically use a set of financial prices and indices (that is smaller than the set of assets that could potentially be included in the portfolio) as the underlying state variables. Most often, historical sample covariances of asset prices are used as estimates of the likely future pattern of comovements. However, this modeling strategy begs the question of what underlying economic forces are driving asset returns. Alternatively, one could include macroeconomic variables such as activity measures, goods prices, policy variables, or business cycle indicators among the state variables in a risk management model. ${ }^{3}$ Such a strategy has several potential advantages in the implementation of risk management models. First, by putting more economic structure on the model, it may help practitioners gain insight into what sort of developments cause the covariance structure of financial prices to change over time, so that their estimates of second moments incorporate all available information. If macroeconomic measures are relevant state variables, they may permit a more parsimonious representation of the state space and thus more precise estimates of the relationships between state variables and the prices of traded assets. In addition, changes in the conditional volatility of a macroeconomic state variable would tend to affect the covariance of asset prices influenced by it -- this sort of modeling strategy could allow for such effects explicitly. Alternatively, the second moments of asset returns could be permitted to depend directly on the level

\footnotetext{
${ }^{3}$ A number of papers have explored the sensitivity of panels of stock return data to macroeconomic risk factors -- see, for example, Chen, Roll, and Ross (1986), King, Sentana, and Wadhwani (1990), and Ammer (1993). However, that branch of the literature has been more focused on testing the arbitrage pricing theory (APT) and seeking out non-zero risk premiums in the context of the APT, rather than measuring asset return covariances as an end in themselves. Campbell and Ammer (1993), in contrast, decompose the covariation in U.S. stock and bond returns into "proximate causes", but their empirical exercises only involve reiationships among financial data.
} 
of a macroeconomic state variable.

This paper investigates several of the above possibilities, with the goal of assessing the usefulness of the inclusion of macroeconomic state variables in risk management models. The next section of the paper uses a simulation exercise to assess the importance of modeling asset returns in terms of the fundamental variables driving them. In the following section, we examine statistical relationships between various potential macroeconomic state variables and monthly returns on fixed-income securities, equities, and foreign exchange instruments of the United States, Japan, Germany, and the United Kingdom. The fourth section of the paper looks into the empirical contribution of state-dependence to time variation in asset return variances and covariances. In the subsequent section, we estimate models in which second moments of returns depend directly on unemployment rates. The sixth section discusses possible refinements to the methods used and some ideas for future research.

\section{Does Factor-Dependence Matter?}

Suppose that a vector of $\mathrm{N}$ asset returns $(\mathrm{Z})$ is a linear function of a set of $\mathrm{K}$ (contemporaneously realized) observable economic factors $(\mathrm{W})$ :

$$
Z_{t}^{\prime}=W_{t}^{\prime} B+u_{t}^{\prime}, \quad u_{t} \perp W_{t}
$$

The $(\mathrm{KxN})$ matrix B contains the factor "loadings". For the time being, we will assume that the conditional means of $(\mathrm{Z})$ and $(\mathrm{W})$ are constant over time, hence, without loss of generality, we can proceed as if these means are zero and omit intercept terms to simplify equations such as (1). Further suppose that the factors $(\mathrm{W})$ and the return residuals $(\mathrm{u})$ are both homoskedastic, so that 


$$
\operatorname{Var}_{t-1}\left(W_{t}\right) \equiv E_{t-1}\left(W_{t} W_{t}\right)=\Omega, \quad \forall t
$$

and

$$
\operatorname{Var}_{t-1}\left(u_{t}\right)=U, \quad \forall t
$$

If the factor loading matrix (B) is also constant over time, then the asset returns $(\mathrm{Z})$ will also be homoskedastic. In particular:

$$
\operatorname{Var}_{t-1}\left(Z_{t}\right)=B^{\prime} \Omega B+U, \forall t
$$

Under these circumstances, particularly without knowledge of the true values of the factor loadings (B), it is not helpful to use data on (W) to estimate the (constant) covariance matrix of (Z) -- it would be more efficient to simply compute the sample moments of $(\mathrm{Z})$.

However, now suppose that the second moments of the factors (W) vary over time. For example, they might each follow independent generalized auto-regressive conditionally heteroskedastic (GARCH) processes. ${ }^{4}$ For a $\mathrm{GARCH}(1,1)$ process, the conditional variance of a factor would evolve as follows:

$$
V_{k, t} \equiv \operatorname{Var}_{t-1}\left(W_{k, t}\right)=c_{k}+a_{k} V_{k, t-1}+d_{k} W_{k, t-1}^{2}
$$

Because $(\mathrm{Z})$ is a function of $(\mathrm{W})$ through equation (1), the second moments of the asset returns $(\mathrm{Z})$ will now vary over time. For example if two asset returns both depend positively on a particular factor, their correlation will tend to rise (or become less negative) when the conditional variance of

\footnotetext{
${ }^{4}$ See Bollerslev (1986) for details on the properties of GARCH models.
} 
that factor is relatively high.

Simulated values of $(\mathrm{W})$ and $(\mathrm{Z})$ were created for a version of the model described by equations (5), (3), and (1) with the help of a random number generator. The model has two observable factors and two asset returns. The parameters, which are given in the central column of panel $\mathrm{A}$ of Table 1 , were chosen to produce a high degree of heteroskedasticity (via the coefficients a and d) and time variation in the correlation of the two asset returns (through B). The residuals (u) are independent and identically distributed, and the (W) and the (u) are all mutually orthogonal and distributed normal. The data were simulated for 2000 periods. Estimated parameters of the true model appear in the rightmost column of panel A. They were computed via a numerical maximum likelihood procedure applied to the first 1000 observations.

Two alternative models of the second moments of $(Z)$ were estimated over the same sample -- each ignores information that might be in (W). Estimates are in Panel B of the table. The first is a bivariate $\operatorname{GARCH}(1,1)$ specification in $(\mathrm{Z})$ with a constant correlation between the two asset returns. ${ }^{5}$ The second is a constant variance-covariance matrix.

For each model, estimated conditional second moments were computed over the second half of the simulated sample. The fit of the models was assessed by using them to compute the value-at-risk (VaR) for each period of four sample portfolios, and comparing the VaR measures based on estimated models to the true $\mathrm{VaR}$ (from the data generating process). VaR is defined here as the five percent left tail of the one-period return.

The results are in the four panels of Table 2. Note the significant degree of time variation in the true VaR. Not surprisingly, the VaR measure based on estimating the true model performs superbly. The correlation with the true VaR exceeds 99 percent in all four cases. The VaR

\footnotetext{
${ }^{5}$ Alternatively, we could have estimated a less parsimonious but more general bivariate GARCH model, such as that of Chan, Karolyi, and Stulz (1994).
} 
based on the GARCH model in asset returns fares fairly well much of the time, but is occasionally off by amounts on the order of 100 percent of the correct $\mathrm{VaR} .{ }^{6}$ The homoskedastic model cannot, of course, capture any time variation in moments, and its VaR tends to exceed the average true VaR somewhat.

\section{To What Extent Does Macroeconomic News Drive Asset Returns?}

A necessary step in implementing the model of the previous section with real data is to estimate factor loadings (B). One must first acquire some observable macroeconomic factors (W). This was accomplished by estimating a $\operatorname{VAR}(6)$ in monthly data in twelve candidate macroeconomic variables -- in particular, CPI inflation, industrial production growth, and the end-of-month overnight call money rate for each of four countries: the United States, Japan, Germany, and the United Kingdom. ${ }^{7}$ Innovations in overnight interest rates likely reflect new information about monetary policy.

Asset price data were collected for the same countries, mostly fixed income instruments in the four currencies. The appendix describes how data on interest rates and yields were converted into one-month holding period returns. The return data used are end-of-month, in percent-per-month units, and measured in dollars.

Table 3 shows the $R^{2}$ for each return regressed on the 12 factor variables. These $R^{2}$

${ }^{6}$ When the estimation sample was extended to 10,000 periods, the VaR measure based on the true model tracked the true VaR even more closely, but the VaR based on the GARCH-in-returns model was no more accurate than when it was computed from estimates obtained from the shorter sample period.

${ }^{7}$ The residuals from these regressions were then orthogonalized in the following order: U.S. (CPI) inflation, Japanese inflation, German inflation, U.K. inflation, U.S. industrial production, Japanese industrial production, German industrial production, U.K. industrial production, the U.S. call money rate (federal funds), the Japanese call money rate, the German call money rate, and the U.K. call money rate. The point of the orthogonalization is to facilitate interpretation of estimated factor loadings. Note that this transformation has no effect on the $\mathbf{R}^{2}$ for each asset that is reported in Table 3. 
are generally on the order of ten to fifteen percent, implying that macroeconomic shocks account for a small. but non-zero portion of asset return variation. Chen, Roll, and Ross (1986), King, Sentana, and Wahdwani (1990), and Rodrigues (1995) have documented substantially greater explanatory power for monthly returns. However these papers use a broader set of "economic variables", including such measures that are based on either monthly asset returns or very similar variables, such as aggregate stock returns, interest rate spreads, and changes in commodity prices. Because the goal here is to introduce variables that are not already being employed in risk management models, we do not consider asset returns and financial prices for the set of candidate state variables. An exception is made for the call money rate, because it is arguably an instrument of monetary policy rather than freely determined by market forces. (In addition, its overnight maturity is substantially shorter than our monthly sampling interval.)

\section{Estimating Factor Heteroskedasticity and Conditional Moments}

Here, we estimate the model that was simulated in section 2 of the paper. Recall that it allows returns to depend on conditionally heteroskedastic observable factors, but has no other source of time variation in second moments. ${ }^{8}$ The first step is to estimate equation $(5)$, the $\operatorname{GARCH}(1,1)$ models of the observable underlying factors, using the same (ortho-normalized) macroeconomic news proxies as in the regressions described in the previous section. The parameter estimates appear in Table 4. The rightmost column shows the results of a likelihood ratio test against the null hypothesis of homoskedasticity. Note that only in three cases (the Japanese inflation shock and the U.S. and Japanese monetary policy shocks) is the null rejected with 95 percent confidence.

\footnotetext{
${ }^{8}$ Because the focus of this paper is on second moments, we will ignore the possibility of time variation in mean returns, throughout.
} 
Next, equation (1) is estimated. ${ }^{9}$ Panel $\mathrm{A}$ of Table 5 shows results for a system including returns on two assets -- the UK 20-year bond and a Japanese equity index. Most of the estimates are not significantly different from zero. Panel B shows estimates of the two alternative models also discussed in section 2: $\operatorname{GARCH}(1,1)$ in the returns themselves and homoskedasticity. Panel $\mathrm{C}$ shows the $\log$ likelihood function for the three estimated models. Note that the factor-based model has a substantially higher log likelihood than the "GARCH in returns" model -- albeit, using 27 parameters instead of 7 -- but neither model causes the null of homoskedasticity to be rejected in a likelihood ratio (LR) test. ${ }^{10}$ Panel D compares the projected conditional moments from the estimated models to the cross products of subsequently realized returns. The correlation coefficients imply that neither estimated model has any ability to forecast changes in second moments. Apparently, to the extent there is conditional heteroskedasticity in these two asset returns, neither specification has been very successful in capturing it.

Table 6 runs through the analogous empirical exercises for a 1-year German government bond and a 7-year German government bond, the (dollar) returns on which are very highly correlated. As in Table 5, neither of the two models of time variation in asset return moments appears to fit the data well. One cannot reject the null hypothesis of homoskedasticity against either alternative, and neither model (Panel D) exhibits any ability to forecast variances and covariances of returns.

The failure to reject homoskedasticity in favor of the factor-based heteroskedastic model may be in part because the factor-based model has too many parameters -- most of the factor

\footnotetext{
${ }^{9}$ Note that estimating (5) and (1) sequentially yields the same results as estimating the two equations simultaneously, because $\mathrm{u}$ and $\mathrm{W}$ are orthogonal by construction. It would have been better to have estimated the orthogonalization of W, (5), and (1) all simultaneously, although it would have been much more difficult computationally.

${ }^{10}$ It is possible that a more parsimonious factor-based model would have led to rejection of the null hypothesis of homoskedasticity, but we wanted to avoid data mining.
} 
loadings reported in panel $\mathrm{A}$ of tables 5 and 6 are not significantly different from zero. In table 5 , only the factors associated with U.S. inflation, U.S. and Japanese output growth, and the Japanese call money rate are significant with 95 percent confidence (for a one-sided test) for one of the two returns. Accordingly, table 7 reports results from a more parsimonious factor-based model of the UK 20-year bond and the Japanese equity index, using only these four factors. " As can be inferred from panel B of the table, an LR test now rejects homoskedasticity in favor of the factor-based model. However, as shown in panel $\mathrm{C}$. the model still does a poor job of explaining time variation in second moments -its forecast of the UK bond return variance is still negatively correlated with squared returns, and the other reported correlations are still close to zero. Thus, our LR rejection appears to derive from the estimated conditional variance in the factor model being on average lower than the unconditional variance, rather than the time variation in the model's conditional variance tracking the true conditional variance. In other words, the introduction of the macroeconomic variables into the model contributes by improving our estimates of the conditional means of the returns, not the conditional second moments.

Table 8 shows the results of an analogous modeling strategy for the German 1-year and 7-year bonds. Homoskedasticity is rejected in favor of a more parsimonious factor-based model that uses only the factors associated with U.S. inflation and industrial production. This factor-based model produces forecasts of second moments that are weakly correlated with the cross-products of returns, but none of these correlations are significantly different from zero with 95 percent confidence. ${ }^{12}$

\footnotetext{
11 Note that the other eight macroeconomic variables are involved in the construction of these factors, both through the VAR equations and through the orthogonalization.

${ }^{12}$ Given a sample size of 120 , a correlation coefficient of .15 or greater would be significant with 95 percent confidence.
} 


\section{Direct State-Dependence of Second Moments}

Accordingly, it may be worth exploring other types of conditional heteroskedasticity involving macroeconomic variables. Another way to model state-dependent heteroskedasticity involves creating a lower triangular matrix $\mathrm{L}$ whose elements (on or below the diagonal) are linear functions of particular state variables: ${ }^{13}$

$$
L_{(i, j),}=\alpha_{i j, 0}=\sum_{m=1}^{M} \alpha_{i j, m} S_{m, t-1} \text { for } i \geq j
$$

and

$$
L_{(i, j), t}=0 \quad \text { for } i<j
$$

Assuming $L$ is full rank, the matrix $L^{\prime}$ is symmetric and positive definite, and thus admissible as the variance-covariance matrix of returns:

$$
\operatorname{Var}_{t-1}\left(Z_{t}\right)=L_{t} L_{t}^{\prime}
$$

The parameters entering $L$ can be estimated by numerical maximum likelihood methods. ${ }^{14}$ One advantage of a specification of this sort is that it is more flexible than specifications based on

${ }^{13}$ This strategy differs somewhat from the approach of McQueen and Roley (1993), who used the level of industrial production relative to trend to define three discrete economic states. They found state-dependence in the sensitivity of U.S. stock returns to news contained in consumer price index announcements.

14 Note that the matrix $\mathrm{L}$ is not a unique lower triangular decomposition of the variance-covariance matrix. In particular, any row of $L$ could be multiplied by -1 and (8) would still hold. (In fact, it can be shown that this type of transformation yields all possible lower triangular decompositions of a symmetric positive-definite matrix.) However, since the parameters of interest are the variance-covariance matrix itself. rather than $\mathrm{L}$. the indeterminacy of $\mathrm{L}$ is not important. 
univariate GARCH models in the nature of state-dependence in covariance that it permits. The biggest drawback is the number of parameters that must be estimated. Fortunately, this disadvantage was tempered in the applications we tried by a well-behaved likelihood function that was well-suited for numerical estimation via quadratic approximation.

Tables 9 and 10 show estimates of models of this sort, using unemployment rates as the state variables. The state variables are lagged two months, so that the data is public at the beginning of the period over which returns are measured. ${ }^{15}$ The upper panel of each table contains the estimated second moments of the asset returns, when the state variables at their sample mean. Subsequently, the tables show the incremental effect, relative to the baseline case of Panel A, of raising one of the unemployment rates by one percentage point. (Because the relation between the moments and the state variables is quadratic, the effect of a two percentage point increase generally is not twice as much.) In both cases, the null hypothesis of homoskedasticity is rejected against this alternative. Note that U.S. bond returns -- both short and long -- are estimated to be both more volatile and more highly correlated with other asset returns when the U.S. unemployment rate is high. The increase in the variances is significant with 95 percent confidence. This suggests that, when the economy is weak, there is more uncertainty about the future course of real interest rates, inflation, or both -- bad times are uncertain times.

Panel C of Table 10 shows a similar but weaker (and not statistically significant) effect on the variance of the U.K. 10-year bond return (but not on its correlation with other asset returns) when British unemployment is high. Interestingly, the effects of unemployment in the two countries on the volatility of the bilateral exchange rate (reflected in the dollar return on the 1-period sterling Euro-instrument) are estimated to be of opposite sign, although neither is significantly different from

${ }^{15}$ Like results were obtained with a one-month lag and with no lag. The similarity in the estimates under these alternatives is not surprising, given that the unemployment rate moves slowly over time. 
zero. Note also that none of the off-diagonal elements in the lower panel are significantly different from zero (in the statistical sense). If the true parameters are zero, this implies that an adequate measure of the effect of a change in the unemployment rate on the covariance between two asset returns can be computed from the effects on the variances of the two asset returns.

Another way that one can compare the performance of the models with direct state-dependence in second moments to the GARCH models is through the correlation between the conditional second moments the models produce and the actual cross-products of returns. In general, we measure correlations somewhat larger than those reported in Tables 5, 6, 7, and 8 . For the 3-return and 1-state model of Table 9, all 6 correlations are positive, ranging from 5 percent (for the variance of the 1-year bond return) to 11 percent (for the variance of the 10 -year bond return). For the 6-return and 2-state model of Table 10, 20 of 21 correlations are positive, running as high as 28 percent for the covariance between the U.S. 1-year bond and 10-year bond returns.

\section{Conclusions and Future Possibilities}

The results described in the previous section imply that, in some cases, models that allow the conditional variance of one set of variables to depend directly on lagged values of a second set of variables can provide better forecasts of second moments than GARCH models. These models are non-linear and involve a large number of parameters. Thus, future work might explore alternative estimation methods to the straightforward numerical maximum likelihood method used here. In addition, it would be interesting to explore whether our finding that bond return volatility is increasing in the unemployment rate is robust across a broader sample of countries. It also would be worthwhile to consider what sort of economic models would be consistent with this stylized fact.

We found less support for models that involve linear relations between macroeconomic news variables and asset returns. Although the more parsimonious models we tried fit the data 
somewhat better than a simple homoskedastic model of returns, we found little or no forecasting power for second moments. The weak results do not necessarily mean that observable state variables are not an important determinant of asset price covariances -- it may be simply that a VAR at a monthly frequency is an inferior way to measure news. An alternative would be to measure shocks in the macro variables relative to survey expectations of their values some time before the announcement. This would have the further advantage of making it feasible to apply the technique to higher frequency data. 


\section{Appendix: Construction of Monthly Bond Returns from Yield Data}

\section{coupon bonds}

We assume that the reported annualized $n$-month yield to maturity $\left(Y_{n,}\right)$ applies to a hypothetical n-month bond with monthly coupons that is trading at par. For a bond with a face value of one, the monthly coupon would be:

$$
C_{n, t}=\left(1+\frac{Y_{n, t}}{100}\right)^{\frac{1}{12}}-1
$$

Also define the monthly discount factor pertaining to the stated annualized yield to maturity:

$$
M_{n, t}=\left(1+\frac{Y_{n, t}}{100}\right)^{\frac{-1}{12}}
$$

Because the bond is trading at par and it is assumed to have unit face value, its price is one. The present value of the cash flow from the bond, discounted at its yield, must equal the price:

$$
1=M_{n, t}^{n}+C_{n, t} \sum_{k=1}^{n} M_{n, t}{ }^{k}
$$

In order to compute the capital gain component of the one-month return on the bond, we will approximate the current yield to maturity of the previous month's hypothetical n-month par bond with monthly coupons (now a bond with a maturity of $n-1$ months) with the reported $n$-month yield ( $\left.Y_{n, t}\right)$. Thus its price may be written as:

$$
P_{n-1, t}=M_{n-1, t}^{n-1}+C_{n, t-1} \sum_{k=1}^{n-1} M_{n-1, t}^{k} \approx M_{n, t}^{n-1}+C_{n, t-1} \sum_{k=1}^{n-1} M_{n, t}^{k}
$$

The return on the bond between ( $t-1)$ and $t$ takes into account both the coupon payment and the change in the price. Expressed in percent, the return is:

$$
R_{n, t}=100\left(C_{n, t-1}+P_{n-1, t}-1\right)
$$

Note that if the n-month yield is unchanged, the return will consist only of its income (coupon) component. 
pure discount bonds

Given its annualized yield to maturity, the price of an n-month pure discount bond (with unit face value) at ( $t-1)$ is

$$
P_{n, t-1}=\left(1+\frac{Y_{n, t-1}}{100}\right)^{\frac{-n}{12}}
$$

Assuming that it has the same yield to maturity as the n-month bond, a discount bond maturing in $\mathrm{n}-1$ months at time $t$ has the price:

$$
P_{n-1, t}=\left(1+\frac{Y_{n-1, t}}{100}\right)^{\frac{1-n}{12}} \approx\left(1+\frac{Y_{n, t}}{100}\right)^{\frac{1-n}{12}}
$$

The return on the bond between $(t-1)$ and $t$ reflects only the change in the price. Expressed in percent, the return is:

$$
R_{n, t}=100 \frac{P_{n-1, t}-P_{n, t-1}}{P_{n, t-1}}
$$

consols

Given annual interest payments of $\mathrm{X}$, the price of a consol of unit face value is an inverse function of its quoted annual yield:

$$
P_{\infty, t}=\frac{X}{Y_{t}}
$$

The return (in percent units) from month $t-1$ to month $t$ comprises a price change component and a monthly interest payment:

$$
R_{t}=100\left(\frac{P_{t}-P_{t-1}}{P_{t-1}}\right)+\frac{Y_{t-1}}{12}=100\left(\frac{Y_{t-1}-Y_{t}}{Y_{t}}\right)+\frac{Y_{t-1}}{12}
$$




\section{References}

Ammer. John (1993), "Macroeconomic Risk and Asset Pricing: Estimating the APT with Observable Factors," International Finance Discussion Paper 448. Federal Reserve Board.

Bollerslev, Tim (1986), "Generalized Auto-Regressive Conditional Heteroskedasticity," Journal of Econometrics 31:307-327.

Campbell, John Y. and John Ammer (1993), "What Moves the Stock and Bond Markets? A Variance Decomposition for Long-Term Asset Returns," Joumal of Finance 48:3-37.

Chan, K.C., Andrew Karolyi, and Rene Stulz (1994), "Global Financial Markets and the Risk Premium on U.S. Equity," NBER Working Paper 4074.

Chen, Naifu, Richard Roll, and Steve Ross (1986), "Economic Forces and the Stock Markets," Journal of Business 59:383-403.

Mervyn King, Enrique Sentana, and Sushil Wadhwani (1990), "A Heteroskedastic Factor Model of Asset Returns and Risk Premia with Time-Varying Volatility: An Application to Sixteen World Stock Markets," Einancial Markets Group Discussion Paper 80, London School of Economics.

McQueen, Grant and Vance Roley (1993), "Stock Prices, News, and Business Conditions" Review of Einancial Studies 6:683-707.

Rodrigues, Anthony (1995), "Why Do Volatilities Sometimes Move Together?" paper prepared for joint central bank conference "Risk Measurement and Systemic Risk," Washington, DC, November 16-17, 1995. 
$-17-$

Table 1: Simulated GARCH in Observable Factors and Model Estimates

\section{A. true model: GARCH $(1,1)$ in 2 observable factors}

\begin{tabular}{|c|c|c||}
\hline parameter & true value & estimated \\
\hline $\mathrm{c}_{1}$ & 0.20 & 0.18 \\
\hline $\mathrm{a}_{1}$ & 0.40 & 0.36 \\
\hline $\mathrm{d}_{1}$ & 0.40 & 0.47 \\
\hline $\mathrm{c}_{2}$ & 0.20 & 0.27 \\
\hline $\mathrm{a}_{2}$ & 0.40 & 0.29 \\
\hline $\mathrm{d}_{2}$ & 0.40 & 0.47 \\
\hline $\mathrm{B}_{1,1}$ & 1.00 & 1.05 \\
\hline $\mathrm{B}_{1,2}$ & 1.00 & 1.02 \\
\hline \hline $\mathrm{B}_{2,1}$ & 1.00 & 1.01 \\
\hline \hline $\mathrm{B}_{2,2}$ & -1.00 & -1.02 \\
\hline$\sigma_{u 1}^{2}$ & 0.25 & 0.23 \\
\hline \hline$\sigma_{u 2}^{2}$ & 0.25 & 0.26 \\
\hline \hline
\end{tabular}

B. alternative models: GARCH $(1,1)$ in returns and homoskedastic returns

\begin{tabular}{|c|c|c|}
\hline parameter estimate & GARCH in returns model & homoskedastic model \\
\hline$c_{1}$ & 0.45 & 2.47 \\
\hline $\mathrm{a}_{1}$ & 0.61 & \\
\hline $\mathrm{d}_{1}$ & 0.21 & 2.34 \\
\hline $\mathrm{c}_{2}$ & 0.47 & \\
\hline $\mathrm{a}_{2}$ & 0.57 & \\
\hline $\mathrm{d}_{2}$ & 0.22 & 0.01 \\
\hline \hline$\rho_{1,2}$ & -0.02 & \\
\hline \hline
\end{tabular}

Note: See text for model definitions. 
Table 2: Actual and Estimated Portfolio "Value-at-Risk" for Simulated Data

A. portfolio weights $=\left(\begin{array}{ll}0 & 100\end{array}\right)^{\prime}$

\begin{tabular}{||l|c|c|c|c||}
\hline statistic & true VaR & GARCH in factors & GARCH in returns & homoskedastic \\
\hline mean VaR & 230.1 & 236.1 & 239.0 & 251.5 \\
\hline std.dev. of VaR & 63.7 & 67.8 & 53.7 & 0 \\
\hline$\rho$ with true VaR & $100.0 \%$ & $99.5 \%$ & $83.5 \%$ & 0 \\
\hline mean lerror & - & 7.3 & 27.3 & 50.8 \\
\hline maximum error & - & 52.7 & 193.2 & 513.3 \\
\hline
\end{tabular}

B. portfolio weights $=\left(\begin{array}{lll}100 & 0\end{array}\right)^{\prime}$

\begin{tabular}{||l|c|c|c|c||}
\hline statistic & true VaR & GARCH in factors & GARCH in returns & homoskedastic \\
\hline mean VaR & 230.1 & 237.0 & 242.7 & 258.8 \\
\hline std.dev. of VaR & 63.7 & 68.5 & 51.0 & 0 \\
\hline$\rho$ with true VaR & $100.0 \%$ & $99.4 \%$ & $82.1 \%$ & 0 \\
\hline mean lerror & - & 8.2 & 30.2 & 54.8 \\
\hline maximum error & - & 53.8 & 216.2 & 506.1 \\
\hline
\end{tabular}

C. portfolio weights $=(100100)^{\prime}$

\begin{tabular}{||l|c|c|c|c||}
\hline statistic & true VaR & GARCH in factors & GARCH in returns & homoskedastic \\
\hline mean VaR & 312.9 & 319.8 & 339.3 & 362.9 \\
\hline std.dev. of VaR & 86.0 & 98.8 & 66.0 & 0 \\
\hline$\rho$ with true VaR & $100.0 \%$ & $99.9 \%$ & $41.5 \%$ & 0 \\
\hline mean lerror & - & 9.9 & 60.3 & 85.4 \\
\hline maximum error & - & 80.0 & 616.8 & 465.7 \\
\hline
\end{tabular}


Table 2 (continued)

D. portfolio weights $=(100-100)^{\prime}$

\begin{tabular}{||l|c|c|c|c||}
\hline statistic & true VaR & GARCH in factors & GARCH in returns & homoskedastic \\
\hline mean VaR & 325.4 & 335.1 & 345.0 & 358.7 \\
\hline std.dev. of VaR & 130.1 & 134.6 & 67.0 & 0 \\
\hline$\rho$ with true VaR & $100.0 \%$ & $99.4 \%$ & $81.9 \%$ & 0 \\
\hline mean lerror & - & 13.4 & 60.6 & 93.4 \\
\hline maximum error & - & 120.1 & 619.8 & 1149.3 \\
\hline
\end{tabular}

Note: Models are as defined in the text. Each specification was estimated over the first 1000 observations of simulated data and then propagated over the subsequent 1000 observations. "Value at risk" is defined as the 5 percent left tail of the one-period return. 
Table 3: Linear Regressions of Asset Returns on Macroeconomic Factors proportion of variance explained, 1/85 - 12/94

\begin{tabular}{|l||c||}
\hline \hline asset return & R-squared \\
\hline U.S. equity index & 0.05 \\
\hline U.S. 30-year bond & 0.11 \\
\hline U.S. 10-year bond & 0.11 \\
\hline U.S. 7-year bond & 0.12 \\
\hline U.S. 5-year bond & 0.12 \\
\hline U.S. 3-year bond & 0.11 \\
\hline U.S. 2-year bond & 0.12 \\
\hline U.S. 1-year bond & 0.09 \\
\hline U.S. 12-month Eurorate & 0.13 \\
\hline U.S. 6-month Eurorate & 0.08 \\
\hline U.S. 3-month Eurorate & 0.02 \\
\hline U.S. 1-month Eurorate & 0.01 \\
\hline Japan equity index & 0.13 \\
\hline Japan 10-year bond & 0.07 \\
\hline Japan 12-year corporate & 0.09 \\
\hline Japan 5-year corporate & 0.09 \\
\hline Japan 12-month Eurorate & 0.09 \\
\hline Japan 6-month Eurorate & 0.09 \\
\hline Japan 3-month Eurorate & 0.09 \\
\hline Japan 1-month Eurorate & 0.10 \\
\hline
\end{tabular}

Note: The factors are the residuals (orthogonalized in the order listed) from a VAR(6) in U.S. inflation, Japanese inflation, German inflation, U.K. inflation, U.S. industrial production, Japanese industrial production, German industrial production, U.K. industrial production, the U.S. call money rate (federal funds), the Japanese call money rate, the German call money rate, and the U.K. call money rate. Returns are end-of-month, in percent-per-month units, and measured in dollars. 
Table 3 (continued)

\begin{tabular}{|c|c|}
\hline asset return & R-squared \\
\hline German equity index & 0.07 \\
\hline German 7-year bond & 0.10 \\
\hline German 5-year bond & 0.10 \\
\hline German 3-year bond & 0.10 \\
\hline German 2-year bond & 0.10 \\
\hline German 1-year bond & 0.11 \\
\hline German 12-month Eurorate & 0.11 \\
\hline German 6-month Eurorate & 0.11 \\
\hline German 3-month Eurorate & 0.10 \\
\hline German 1-month Eurorate & 0.10 \\
\hline U.K. equity index & 0.09 \\
\hline U.K. $3.5 \%$ consol & 0.15 \\
\hline U.K. 20-year bond & 0.14 \\
\hline U.K. 10-year bond & 0.13 \\
\hline U.K. 5-year bond & 0.12 \\
\hline U.K. 12-month Eurorate & 0.14 \\
\hline U.K. 6-month Eurorate & 0.13 \\
\hline U.K. 3-month Eurorate & 0.13 \\
\hline U.K. 1-month Eurorate & 0.13 \\
\hline
\end{tabular}

Note: The factors are the residuals (orthogonalized in the order listed) from a VAR(6) in U.S. inflation, Japanese inflation, German inflation, U.K. inflation, U.S. industrial production, Japanese industrial production, German industrial production, U.K. industrial production, the U.S. call money rate (federal funds), the Japanese call money rate, the German call money rate, and the U.K. call money rate. Returns are end-of-month, in percent-per-month units, and measured in dollars. 
Table 4: Estimates of Univariate GARCH Models of Macroeconomic Factors

\begin{tabular}{|c|c|c|c|c|}
\hline & c & a & d & LR test: $\chi^{2}(2)$ \\
\hline $\begin{array}{l}\text { U.S. CPI } \\
\text { inflation }\end{array}$ & $\begin{array}{c}0.86 \\
(0.38)\end{array}$ & $\begin{array}{c}0.25 \\
(0.37)\end{array}$ & $\begin{array}{l}-0.11 \\
(0.02) \\
\end{array}$ & 2.68 \\
\hline $\begin{array}{l}\text { Japan CPI } \\
\text { inflation }\end{array}$ & $\begin{array}{c}0.67 \\
(0.19) \\
\end{array}$ & $\begin{array}{l}-0.09 \\
(0.12) \\
\end{array}$ & $\begin{array}{c}0.46 \\
(0.19) \\
\end{array}$ & 10.94 \\
\hline $\begin{array}{l}\text { German CPI } \\
\text { inflation }\end{array}$ & $\begin{array}{c}0.67 \\
(0.41) \\
\end{array}$ & $\begin{array}{c}0.24 \\
(0.40) \\
\end{array}$ & $\begin{array}{r}0.09 \\
(0.11) \\
\end{array}$ & 0.79 \\
\hline $\begin{array}{l}\text { U.K. CPI } \\
\text { inflation }\end{array}$ & $\begin{array}{r}1.14 \\
(0.93) \\
\end{array}$ & $\begin{array}{l}-0.07 \\
(0.93) \\
\end{array}$ & $\begin{array}{l}-0.07 \\
(0.06) \\
\end{array}$ & 0.98 \\
\hline $\begin{array}{l}\text { U.S. industrial } \\
\text { output growth }\end{array}$ & $\begin{array}{c}1.91 \\
(0.35) \\
\end{array}$ & $\begin{array}{l}-0.79 \\
(0.14) \\
\end{array}$ & $\begin{array}{l}-0.09 \\
(0.09) \\
\end{array}$ & 1.10 \\
\hline $\begin{array}{l}\text { Japan industrial } \\
\text { output growth }\end{array}$ & $\begin{array}{c}1.34 \\
(0.46) \\
\end{array}$ & $\begin{array}{l}-0.25 \\
(0.45) \\
\end{array}$ & $\begin{array}{l}-0.10 \\
(0.05) \\
\end{array}$ & 2.80 \\
\hline $\begin{array}{l}\text { German industrial } \\
\text { output growth }\end{array}$ & $\begin{array}{c}0.35 \\
(0.11) \\
\end{array}$ & $\begin{array}{c}0.78 \\
(0.12) \\
\end{array}$ & $\begin{array}{l}-0.13 \\
(0.03) \\
\end{array}$ & 5.31 \\
\hline $\begin{array}{l}\text { U.K. industrial } \\
\text { output growth }\end{array}$ & $\begin{array}{c}1.58 \\
(0.52) \\
\end{array}$ & $\begin{array}{l}-0.51 \\
(0.47) \\
\end{array}$ & $\begin{array}{l}-0.06 \\
(0.06) \\
\end{array}$ & 0.60 \\
\hline $\begin{array}{l}\text { U.S. overnight } \\
\text { interest rate }\end{array}$ & $\begin{array}{c}1.68 \\
(0.25) \\
\end{array}$ & $\begin{array}{l}-0.82 \\
(0.12) \\
\end{array}$ & $\begin{array}{c}0.08 \\
(0.02) \\
\end{array}$ & 7.59 \\
\hline $\begin{array}{l}\text { Japan overnight } \\
\text { interest rate }\end{array}$ & $\begin{array}{c}1.81 \\
(0.25) \\
\end{array}$ & $\begin{array}{l}-0.98 \\
(0.03) \\
\end{array}$ & $\begin{array}{c}0.12 \\
(0.04) \\
\end{array}$ & 10.17 \\
\hline $\begin{array}{l}\text { German overnight } \\
\text { interest rate }\end{array}$ & $\begin{array}{c}0.52 \\
(0.44) \\
\end{array}$ & $\begin{array}{c}0.56 \\
(0.44) \\
\end{array}$ & $\begin{array}{l}-0.07 \\
(0.01) \\
\end{array}$ & 3.93 \\
\hline $\begin{array}{l}\text { U.K. overnight } \\
\text { interest rate }\end{array}$ & $\begin{array}{c}1.83 \\
(0.28)\end{array}$ & $\begin{array}{l}-0.90 \\
(0.12)\end{array}$ & $\begin{array}{c}0.08 \\
(0.07)\end{array}$ & 1.91 \\
\hline
\end{tabular}

(standard errors in parentheses) 
Table 5: Three Models of Bivariate Asset Return Variance-Covariance:

UK 20-year bond and Japanese equity index, 1/85 - 12/94

A. linear function of 12 univariate $\operatorname{GARCH}(1,1)$ observable factors (homoskedastic residual)

\begin{tabular}{|c|c|c|}
\hline coefficient & $\begin{array}{l}\text { UK 20-year } \\
\text { bond }\end{array}$ & $\begin{array}{l}\text { Japanese equity } \\
\text { index }\end{array}$ \\
\hline $\begin{array}{l}\text { U.S. CPI } \\
\text { inflation }\end{array}$ & $\begin{array}{l}-0.37 \\
(0.26)\end{array}$ & $\begin{array}{l}-1.47 \\
(0.67)\end{array}$ \\
\hline $\begin{array}{l}\text { Japan CPI } \\
\text { inflation }\end{array}$ & $\begin{array}{l}-0.23 \\
(0.26)\end{array}$ & $\begin{array}{l}-0.64 \\
(0.67)\end{array}$ \\
\hline $\begin{array}{l}\text { German CPI } \\
\text { inflation }\end{array}$ & $\begin{array}{l}-0.38 \\
(0.26)\end{array}$ & $\begin{array}{c}0.41 \\
(0.67)\end{array}$ \\
\hline $\begin{array}{l}\text { U.K. CPI } \\
\text { inflation }\end{array}$ & $\begin{array}{c}0.02 \\
(0.26) \\
\end{array}$ & $\begin{array}{c}0.58 \\
(0.67) \\
\end{array}$ \\
\hline $\begin{array}{l}\text { U.S. industrial } \\
\text { output growth }\end{array}$ & $\begin{array}{l}-0.09 \\
(0.26) \\
\end{array}$ & $\begin{array}{l}-1.54 \\
(0.67) \\
\end{array}$ \\
\hline $\begin{array}{l}\text { Japan industrial } \\
\text { output growth }\end{array}$ & $\begin{array}{l}-0.50 \\
(0.26) \\
\end{array}$ & $\begin{array}{l}-0.15 \\
(0.67) \\
\end{array}$ \\
\hline $\begin{array}{l}\text { German industrial } \\
\text { output growth }\end{array}$ & $\begin{array}{c}0.11 \\
(0.26) \\
\end{array}$ & $\begin{array}{l}-0.76 \\
(0.67) \\
\end{array}$ \\
\hline $\begin{array}{l}\text { U.K. industrial } \\
\text { output growth }\end{array}$ & $\begin{array}{l}-0.14 \\
(0.26) \\
\end{array}$ & $\begin{array}{l}-0.55 \\
(0.67) \\
\end{array}$ \\
\hline $\begin{array}{l}\text { U.S. overnight } \\
\text { interest rate }\end{array}$ & $\begin{array}{c}0.26 \\
(0.26) \\
\end{array}$ & $\begin{array}{c}0.91 \\
(0.67) \\
\end{array}$ \\
\hline $\begin{array}{l}\text { Japan overnight } \\
\text { interest rate }\end{array}$ & $\begin{array}{l}-0.77 \\
(0.26)\end{array}$ & $\begin{array}{l}-0.06 \\
(0.67)\end{array}$ \\
\hline $\begin{array}{l}\text { German overnight } \\
\text { interest rate }\end{array}$ & $\begin{array}{l}-0.19 \\
(0.26) \\
\end{array}$ & $\begin{array}{l}-0.47 \\
(0.67) \\
\end{array}$ \\
\hline $\begin{array}{l}\text { U.K. overnight } \\
\text { interest rate }\end{array}$ & $\begin{array}{c}0.14 \\
(0.26)\end{array}$ & $\begin{array}{l}-0.77 \\
(0.67)\end{array}$ \\
\hline residual variance & 7.98 & 53.13 \\
\hline residual covariance & \multicolumn{2}{|c|}{4.08} \\
\hline
\end{tabular}


Table 5 (continued)

B. alternatives: bivariate GARCH $(1,1)$ with constant correlation and homoskedastic model

\begin{tabular}{|c|c|c||}
\hline parameter estimate & GARCH $(1,1)$ in returns & homoskedastic model \\
\hline$c_{1}$ & 1.67 & 9.32 \\
\hline$a_{1}$ & 0.69 & \\
\hline$d_{1}$ & 0.13 & 61.14 \\
\hline$c_{2}$ & 23.49 & \\
\hline$a_{2}$ & 0.39 & \\
\hline$d_{2}$ & 0.23 & 0.21 \\
\hline \hline$\rho_{1,2}$ & 0.21 & \\
\hline
\end{tabular}

C. log likelihood functions

\begin{tabular}{|c|c|c|c|}
\hline model & factor-based heteroskedastic & GARCH in returns & homoskedastic \\
\hline $\ln \mathscr{L}$ & -701.2 & -714.9 & -718.5 \\
\hline
\end{tabular}

D. correlations of predicted second moments with actual cross-products of asset returns

\begin{tabular}{||c|c|c|c|}
\hline moment & factor-based heteroskedastic & GARCH in returns & homoskedastic \\
\hline $\begin{array}{c}\text { UK bond } \\
\text { variance }\end{array}$ & -0.18 & 0.05 & 0 \\
\hline $\begin{array}{c}\text { equity } \\
\text { variance }\end{array}$ & 0.01 & -0.06 & 0 \\
\hline $\begin{array}{c}\text { co- } \\
\text { variance }\end{array}$ & -0.03 & 0.06 & 0 \\
\hline
\end{tabular}


Table 6: Three Models of Bivariate Asset Return Variance-Covariance:

German 1-year bond and German 7-year bond, 1/85 - 12/94

A. linear function of 12 univariate $\operatorname{GARCH}(1,1)$ observable factors (homoskedastic residual)

\begin{tabular}{|c|c|c|}
\hline coefficient & $\begin{array}{l}\text { German 1-year } \\
\text { bond }\end{array}$ & $\begin{array}{c}\text { German 7-year } \\
\text { bond }\end{array}$ \\
\hline $\begin{array}{l}\text { U.S. CPI } \\
\text { inflation }\end{array}$ & $\begin{array}{l}-0.47 \\
(0.31) \\
\end{array}$ & $\begin{array}{l}-0.61 \\
(0.34) \\
\end{array}$ \\
\hline $\begin{array}{l}\text { Japan CPI } \\
\text { inflation }\end{array}$ & $\begin{array}{c}0.23 \\
(0.31) \\
\end{array}$ & $\begin{array}{c}0.20 \\
(0.34)\end{array}$ \\
\hline $\begin{array}{l}\text { German CPI } \\
\text { inflation }\end{array}$ & $\begin{array}{l}-0.26 \\
(0.31) \\
\end{array}$ & $\begin{array}{l}-0.43 \\
(0.34)\end{array}$ \\
\hline $\begin{array}{l}\text { U.K. CPI } \\
\text { inflation }\end{array}$ & $\begin{array}{l}-0.05 \\
(0.31) \\
\end{array}$ & $\begin{array}{l}-0.09 \\
(0.34) \\
\end{array}$ \\
\hline $\begin{array}{l}\text { U.S. industrial } \\
\text { output growth }\end{array}$ & $\begin{array}{l}-0.82 \\
(0.31) \\
\end{array}$ & $\begin{array}{l}-0.82 \\
(0.34) \\
\end{array}$ \\
\hline $\begin{array}{l}\text { Japan industrial } \\
\text { output growth }\end{array}$ & $\begin{array}{c}0.13 \\
(0.31) \\
\end{array}$ & $\begin{array}{c}0.07 \\
(0.34) \\
\end{array}$ \\
\hline $\begin{array}{l}\text { German industrial } \\
\text { output growth }\end{array}$ & $\begin{array}{c}0.40 \\
(0.31) \\
\end{array}$ & $\begin{array}{c}0.36 \\
(0.34) \\
\end{array}$ \\
\hline $\begin{array}{l}\text { U.K. industrial } \\
\text { output growth }\end{array}$ & $\begin{array}{l}-0.12 \\
(0.31) \\
\end{array}$ & $\begin{array}{l}-0.19 \\
(0.34) \\
\end{array}$ \\
\hline $\begin{array}{l}\text { U.S. overnight } \\
\text { interest rate }\end{array}$ & $\begin{array}{c}0.21 \\
(0.31) \\
\end{array}$ & $\begin{array}{c}0.25 \\
(0.34) \\
\end{array}$ \\
\hline $\begin{array}{l}\text { Japan overnight } \\
\text { interest rate }\end{array}$ & $\begin{array}{c}0.31 \\
(0.31) \\
\end{array}$ & $\begin{array}{c}0.13 \\
(0.34) \\
\end{array}$ \\
\hline $\begin{array}{l}\text { German overnight } \\
\text { interest rate }\end{array}$ & $\begin{array}{l}-0.06 \\
(0.31) \\
\end{array}$ & $\begin{array}{l}-0.08 \\
(0.34) \\
\end{array}$ \\
\hline $\begin{array}{l}\text { U.K. overnight } \\
\text { interest rate }\end{array}$ & $\begin{array}{l}-0.22 \\
(0.31) \\
\end{array}$ & $\begin{array}{l}-0.17 \\
(0.34)\end{array}$ \\
\hline residual variance & 11.87 & 14.26 \\
\hline residual covariance & \multicolumn{2}{|c|}{12.57} \\
\hline
\end{tabular}


Table 6 (continued)

B. alternatives: bivariate GARCH $(1,1)$ with constant correlation and homoskedastic model

\begin{tabular}{|c|c|c|}
\hline parameter estimate & GARCH $(1,1)$ in returns & homoskedastic model \\
\hline$c_{1}$ & 16.59 & 13.27 \\
\hline$a_{1}$ & -0.34 & \\
\hline$d_{1}$ & 0.10 & 15.82 \\
\hline$c_{2}$ & 28.77 & \\
\hline$a_{2}$ & -0.86 & \\
\hline$d_{2}$ & 0.06 & 0.97 \\
\hline \hline$\rho_{1,2}$ & 0.97 & \\
\hline \hline
\end{tabular}

C. $\log$ likelihood functions

\begin{tabular}{|c|c|c|c|}
\hline model & factor-based heteroskedastic & GARCH in returns & homoskedastic \\
\hline $\ln \mathscr{L}$ & -486.0 & -494.9 & -498.5 \\
\hline
\end{tabular}

D. correlations of predicted second moments with actual cross-products of asset returns

\begin{tabular}{||c|c|c|c||}
\hline moment & factor-based heteroskedastic & GARCH in returns & homoskedastic \\
\hline $\begin{array}{c}\text { 1-year } \\
\text { variance }\end{array}$ & 0.01 & 0.02 & 0 \\
\hline $\begin{array}{c}7 \text {-year } \\
\text { variance }\end{array}$ & 0.05 & 0.02 & 0 \\
\hline $\begin{array}{c}\text { co- } \\
\text { variance }\end{array}$ & 0.07 & -0.02 & 0 \\
\hline
\end{tabular}


Table 7: Factor-Based Model of Bivariate Asset Return Variance-Covariance:

UK 20-year bond and Japanese equity index, 1/85 - 12/94

A. linear function of 4 univariate $\operatorname{GARCH}(1,1)$ observable factors (homoskedastic residual)

\begin{tabular}{||l|c|c||}
\hline coefficient & $\begin{array}{c}\text { UK 20-year } \\
\text { bond }\end{array}$ & $\begin{array}{c}\text { Japanese equity } \\
\text { index }\end{array}$ \\
\hline $\begin{array}{l}\text { U.S. CPI } \\
\text { inflation }\end{array}$ & $\begin{array}{l}-0.37 \\
(0.26)\end{array}$ & $\begin{array}{c}-1.47 \\
(0.69)\end{array}$ \\
\hline $\begin{array}{l}\text { U.S. industrial } \\
\text { output growth }\end{array}$ & $\begin{array}{l}-0.09 \\
(0.26)\end{array}$ & $\begin{array}{l}-1.54 \\
(0.69)\end{array}$ \\
\hline Japan industrial & -0.50 & -0.15 \\
output growth & $(0.26)$ & $(0.69)$ \\
\hline Japan overnight & -0.77 & -0.06 \\
interest rate & $(0.26)$ & $(0.69)$ \\
\hline residual variance & 8.34 & 56.57 \\
\hline residual covariance & \multicolumn{2}{|c|}{4.29} \\
\hline
\end{tabular}

(standard errors in parentheses)

B. log likelihood functions

\begin{tabular}{|c|c|c|c|}
\hline model & factor-based heteroskedastic & GARCH in returns & homoskedastic \\
\hline $\ln \mathscr{L}$ & -707.5 & -714.9 & -718.5 \\
\hline
\end{tabular}

C. correlations of predicted second moments with actual cross-products of asset returns

\begin{tabular}{|c|c|c|c|}
\hline moment & factor-based heteroskedastic & GARCH in returns & homoskedastic \\
\hline $\begin{array}{c}\text { UK bond } \\
\text { variance }\end{array}$ & -0.21 & 0.05 & 0 \\
\hline $\begin{array}{c}\text { equity } \\
\text { variance }\end{array}$ & 0.08 & -0.06 & 0 \\
\hline $\begin{array}{c}\text { co- } \\
\text { variance }\end{array}$ & -0.05 & 0.06 & 0 \\
\hline
\end{tabular}


Table 8: Factor-Based Model of Bivariate Asset Return Variance-Covariance:

German 1-year bond and German 7-year bond, 1/85 - 12/94

A. linear function of 2 univariate $\operatorname{GARCH}(1,1)$ observable factors (homoskedastic residual)

\begin{tabular}{||l|c|c||}
\hline coefficient & $\begin{array}{c}\text { German 1-year } \\
\text { bond }\end{array}$ & $\begin{array}{c}\text { German 7-year } \\
\text { bond }\end{array}$ \\
\hline $\begin{array}{l}\text { U.S. CPI } \\
\text { inflation }\end{array}$ & -0.47 & -0.61 \\
$(0.32)$ & $(0.35)$ \\
\hline U.S. industrial & -0.82 & -0.82 \\
output growth & $(0.32)$ & $(0.35)$ \\
\hline residual variance & 12.37 & 14.78 \\
\hline residual covariance & \multicolumn{2}{|c|}{13.04} \\
\hline
\end{tabular}

(standard errors in parentheses)

B. log likelihood functions

\begin{tabular}{|c|c|c|c|}
\hline model & factor-based heteroskedastic & GARCH in returns & homoskedastic \\
\hline $\ln \mathscr{L}$ & -493.4 & -494.9 & -498.5 \\
\hline
\end{tabular}

C. correlations of predicted second moments with actual cross-products of asset returns

\begin{tabular}{||c|c|c|c|}
\hline moment & factor-based heteroskedastic & GARCH in returns & homoskedastic \\
\hline $\begin{array}{c}\text { 1-year } \\
\text { variance }\end{array}$ & 0.11 & 0.02 & 0 \\
\hline $\begin{array}{c}\text { 7-year } \\
\text { variance }\end{array}$ & 0.13 & 0.02 & 0 \\
\hline $\begin{array}{c}\text { co- } \\
\text { variance }\end{array}$ & 0.14 & -0.02 & 0 \\
\hline
\end{tabular}


Table 9: Return Covariance Matrix as Direct Function of Observable State Variable (1/71-12/94)

A. second moments of returns with state variable (US unemployment) at sample mean

\begin{tabular}{|l|c|c|c||}
\hline $\begin{array}{l}\text { variances on diagonal; } \\
\text { correlations (lower L } \Delta \text { ) }\end{array}$ & $\begin{array}{c}\text { US } \\
\text { equity }\end{array}$ & $\begin{array}{c}\text { 10-year } \\
\text { US bond }\end{array}$ & $\begin{array}{c}\text { 1-year } \\
\text { US bond }\end{array}$ \\
\hline US equity & $\begin{array}{c}19.29 \\
(1.61)\end{array}$ & & \\
\hline 10-year US bond & $\begin{array}{c}0.32 \\
(0.05)\end{array}$ & $\begin{array}{c}5.70 \\
(0.48)\end{array}$ & \\
\hline 1-year US bond & $\begin{array}{c}0.19 \\
(0.06)\end{array}$ & $\begin{array}{c}0.76 \\
(0.02)\end{array}$ & $\begin{array}{c}0.38 \\
(0.03)\end{array}$ \\
\hline
\end{tabular}

B. effect on second moments of US unemployment being 1 percentage point higher (versus A.)

\begin{tabular}{|l|c|c|c||}
\hline $\begin{array}{l}\text { variances on diagonal; } \\
\text { correlations (lower L } \Delta \text { ) }\end{array}$ & $\begin{array}{c}\text { US } \\
\text { equity }\end{array}$ & $\begin{array}{c}\text { 10-year } \\
\text { US bond }\end{array}$ & $\begin{array}{c}\text { 1-year } \\
\text { US bond }\end{array}$ \\
\hline US equity & $\begin{array}{c}-1.63 \\
(1.01)\end{array}$ & & \\
\hline 10-year US bond & $\begin{array}{c}0.03 \\
(0.04)\end{array}$ & $\begin{array}{c}1.19 \\
(0.50)\end{array}$ & \\
\hline 1-year US bond & $\begin{array}{c}0.05 \\
(0.04)\end{array}$ & $\begin{array}{c}0.00 \\
(0.02)\end{array}$ & $\begin{array}{c}0.07 \\
(0.03)\end{array}$ \\
\hline
\end{tabular}

C. likelihood ratio test versus null hypothesis of homoskedasticity

LR (distributed $\chi^{2}$ with 6 degrees of freedom under null) $=15.0$

Note: Variance-covariance matrix is constructed as $L L^{\prime}$ where each element of the lower triangular matrix $\mathrm{L}$ is a linear function of the state variables. Returns are measured in dollars. 
Table 10: Return Covariance Matrix as Direct Function of Observable States, 1/80-12/94

A. second moments of returns with state variables (US and UK unemployment) at sample means

\begin{tabular}{||l|c|c|c|c|c|c||}
\hline \begin{tabular}{|} 
variances on diagonal; \\
correlations (lower L $\Delta$ )
\end{tabular} & $\begin{array}{c}\text { 10-year } \\
\text { US bond }\end{array}$ & $\begin{array}{c}\text { 10-year } \\
\text { UK bond }\end{array}$ & $\begin{array}{c}\text { 1-month } \\
\text { UK Euro }\end{array}$ & $\begin{array}{c}\text { US } \\
\text { equity }\end{array}$ & $\begin{array}{c}\text { UK } \\
\text { equity }\end{array}$ & $\begin{array}{c}\text { 1-year } \\
\text { US bond }\end{array}$ \\
\hline 10-year US bond & $\begin{array}{c}7.25 \\
(1.06)\end{array}$ & & & & & \\
\hline 10-year UK bond & $\begin{array}{c}0.41 \\
(0.09)\end{array}$ & $\begin{array}{c}7.42 \\
(1.03)\end{array}$ & & & & \\
\hline 1-month UK Euro & $\begin{array}{c}0.15 \\
(0.12)\end{array}$ & $\begin{array}{c}0.16 \\
(0.12)\end{array}$ & $\begin{array}{c}13.66 \\
(1.83)\end{array}$ & & & \\
\hline US equity & $\begin{array}{c}0.34 \\
(0.11)\end{array}$ & $\begin{array}{c}0.27 \\
(0.10)\end{array}$ & $\begin{array}{c}-0.03 \\
(0.13)\end{array}$ & $\begin{array}{c}18.37 \\
(2.96)\end{array}$ & & \\
\hline UK equity & $\begin{array}{c}0.26 \\
(0.11)\end{array}$ & $\begin{array}{c}0.50 \\
(0.10)\end{array}$ & $\begin{array}{c}0.55 \\
(0.09)\end{array}$ & $\begin{array}{c}0.54 \\
(0.08)\end{array}$ & $\begin{array}{c}35.62 \\
(5.23)\end{array}$ & \\
\hline 1-year US bond & $\begin{array}{c}0.80 \\
(0.05)\end{array}$ & $\begin{array}{c}0.33 \\
(0.11)\end{array}$ & $\begin{array}{c}0.15 \\
(0.15)\end{array}$ & $\begin{array}{c}0.16 \\
(0.14)\end{array}$ & $\begin{array}{c}0.14 \\
(0.11)\end{array}$ & $\begin{array}{c}0.38 \\
(0.05)\end{array}$ \\
\hline
\end{tabular}

B. effect on second moments of US unemployment being 1 percentage point higher (versus A.)

\begin{tabular}{||l|c|c|c|c|c|c||}
\hline $\begin{array}{l}\text { variances on diagonal; } \\
\text { correlations (lower L } \Delta \text { ) }\end{array}$ & $\begin{array}{c}\text { 10-year } \\
\text { US bond }\end{array}$ & $\begin{array}{c}\text { 10-year } \\
\text { UK bond }\end{array}$ & $\begin{array}{c}\text { 1-month } \\
\text { UK Euro }\end{array}$ & $\begin{array}{c}\text { US } \\
\text { equity }\end{array}$ & $\begin{array}{c}\text { UK } \\
\text { equity }\end{array}$ & $\begin{array}{c}\text { 1-year } \\
\text { US bond }\end{array}$ \\
\hline 10-year US bond & $\begin{array}{c}1.77 \\
(1.75)\end{array}$ & & & & & \\
\hline 10-year UK bond & $\begin{array}{c}0.03 \\
(0.10)\end{array}$ & $\begin{array}{c}0.62 \\
(1.00)\end{array}$ & & & & \\
\hline 1-month UK Euro & $\begin{array}{c}0.10 \\
(0.11)\end{array}$ & $\begin{array}{c}0.00 \\
(0.11)\end{array}$ & $\begin{array}{c}-1.33 \\
(2.17)\end{array}$ & & & \\
\hline US equity & $\begin{array}{c}0.02 \\
(0.10)\end{array}$ & $\begin{array}{c}-0.02 \\
(0.08)\end{array}$ & $\begin{array}{c}0.05 \\
(0.11)\end{array}$ & $\begin{array}{c}-1.31 \\
(2.09)\end{array}$ & & \\
\hline UK equity & $\begin{array}{c}0.13 \\
(0.11)\end{array}$ & $\begin{array}{c}-0.05 \\
(0.10)\end{array}$ & $\begin{array}{c}0.10 \\
(0.08)\end{array}$ & $\begin{array}{c}-0.15 \\
(0.10)\end{array}$ & $\begin{array}{c}-1.64 \\
(5.94)\end{array}$ & \\
\hline 1-year US bond & $\begin{array}{c}0.00 \\
(0.04)\end{array}$ & $\begin{array}{c}0.03 \\
(0.10)\end{array}$ & $\begin{array}{c}0.06 \\
(0.13)\end{array}$ & $\begin{array}{c}0.03 \\
(0.10)\end{array}$ & $\begin{array}{c}0.13 \\
(0.13)\end{array}$ & $\begin{array}{c}0.23 \\
(0.09)\end{array}$ \\
\hline
\end{tabular}


Table 10 (continued)

C. effect on second moments of UK unemployment being 1 percentage point higher (versus A.)

\begin{tabular}{|c|c|c|c|c|c|c|}
\hline $\begin{array}{l}\text { variances on diagonal; } \\
\text { correlations (lower L } \Delta \text { ) }\end{array}$ & $\begin{array}{l}\text { 10-year } \\
\text { US bond }\end{array}$ & $\begin{array}{l}\text { 10-year } \\
\text { UK bond }\end{array}$ & $\begin{array}{l}\text { 1-month } \\
\text { UK Euro }\end{array}$ & $\begin{array}{l}\text { US } \\
\text { equity }\end{array}$ & $\begin{array}{l}\text { UK } \\
\text { equity }\end{array}$ & $\begin{array}{l}\text { 1-year } \\
\text { US bond }\end{array}$ \\
\hline 10-year US bond & $\begin{array}{l}-0.77 \\
(0.45)\end{array}$ & & & & & \\
\hline 10-year UK bond & $\begin{array}{l}-0.01 \\
(0.05)\end{array}$ & $\begin{array}{c}0.33 \\
(0.61)\end{array}$ & & & & \\
\hline 1-month UK Euro & $\begin{array}{l}-0.02 \\
(0.06)\end{array}$ & $\begin{array}{l}-0.02 \\
(0.06)\end{array}$ & $\begin{array}{c}1.51 \\
(1.24)\end{array}$ & & & \\
\hline US equity & $\begin{array}{c}0.01 \\
(0.07)\end{array}$ & $\begin{array}{l}-0.05 \\
(0.06)\end{array}$ & $\begin{array}{l}-0.06 \\
(0.07)\end{array}$ & $\begin{array}{c}0.76 \\
(1.87)\end{array}$ & & \\
\hline UK equity & $\begin{array}{c}0.03 \\
(0.07)\end{array}$ & $\begin{array}{l}-0.02 \\
(0.06)\end{array}$ & $\begin{array}{l}-0.05 \\
(0.06)\end{array}$ & $\begin{array}{c}0.01 \\
(0.04)\end{array}$ & $\begin{array}{l}-0.19 \\
(3.16)\end{array}$ & \\
\hline 1-year US bond & $\begin{array}{l}-0.03 \\
(0.02)\end{array}$ & $\begin{array}{l}-0.00 \\
(0.07)\end{array}$ & $\begin{array}{l}-0.05 \\
(0.07)\end{array}$ & $\begin{array}{l}-0.01 \\
(0.09)\end{array}$ & $\begin{array}{l}-0.01 \\
(0.07)\end{array}$ & $\begin{array}{l}-0.12 \\
(0.03)\end{array}$ \\
\hline
\end{tabular}

D. likelihood ratio test versus null hypothesis of homoskedasticity

LR (distributed $\chi^{2}$ with 42 degrees of freedom under null) $=131.0$

Note: Variance-covariance matrix is constructed as $\mathrm{LL}^{\prime}$ where each element of the lower triangular matrix $\mathrm{L}$ is a linear function of the state variables. Returns are measured in dollars. 